1.02

\title{
Anton Bebler* \\ On the Global Impact of the Russian October Revolution of 1917
}

\section{IZVLEČEK}

\section{O GLOBALNEM UČINKU RUSKE OKTOBRSKE REVOLUCIJE}

\section{IZ LETA 1917}

Ruska Oktobrska revolucija leta 1917 je pretresla politični red v Evropi, povzročila pomembne geopolitične spremembe na dveh celinah in več desetletij bolj ali manj intenzivno vplivala na politiko na šestih celinah. Vendar pa ji ni uspelo uresničiti najpomembnejšega razglašenega strateškega cilja - uničiti in ukiniti svetovni kapitalizem. Poleg tega je v lastni državi in večini Evrope postala diskreditirana, kar pa se ni zgodilo $v$ številnih neevropskih državah, zlasti v Aziji.

Ključne besede: ruska revolucija, komunizem, Lenin, kominterna, Sovjetska zveza

\section{ABSTRACT}

The 1917 Russian October Revolution upset the political order in Europe, causing a significant geopolitical change on two continents and exerting various degrees of influence on the politics on six continents for several decades. However, the Revolution failed in its primary declared strategic objective - to destroy and abolish world capitalism. Moreover, it became discredited in its own country of origin and in most of Europe - much more than in many non-European countries, particularly Asia.

Keywords: Russian Revolution, communism, Lenin, Comintern, Soviet Union 
The Great Russian Revolution of 1917, popularly called the October Revolution, was preceded by the short-lived February Revolution. The latter brought about the replacement of the imperial government, the abdication of the head of one of the oldest European monarchies, and the introduction of a dual rule of the "Provisional Committee of the State Duma" (provisioned government) and of the "Soviets of Workers' and Soldiers' Deputies". In the following months the Provisional government lost control of the capital and its military garrison. The state takeover was declared by the Military Revolutionary Committee of the Petrograd Soviet, at 10 in the morning on 25 October 1917. By then, Prime and Defense Minister A. Kerensky had already escaped from the besieged Winter Palace in a car provided by the US Embassy, masquerading as a Serbian officer. The unopposed arrest of most ministers of the already powerless Provisional government took place in the following night, on 26 October, at 2:30 a.m. It was actually a rather unimportant episode accompanied by a mob looting the Winter Palace. ${ }^{1}$ The blank salvo from the cruiser Aurora and the storming of the Winter Palace were later magnified by the Bolshevik propaganda into the symbols of the glorious October Revolution.

Led by the Russian left-wing social democrats (the Bolsheviks), the barely successful October Revolution called for the termination of World War I with a "just and democratic peace" without any annexations and reparations; for the complete abolition of world capitalism and imperialism; as well as for its replacement with the dictatorship of proletariat in the classless societies of the world federation of Soviet republics. According to the Bolsheviks, this was to be a step towards the abolition of the state as such. ${ }^{2}$ The October Revolution also contained a strong antireligious and anticlerical component.

The Russian October Revolution could not put a stop to the savagery of World War I - in fact it even prolonged it, possibly by several months. The breakdown of the Imperial Russian Army and the conclusion of the hugely rewarding and separate peace treaty with the Soviet Russia in March 1918 allowed Germany and AustroHungary to continue fighting until November 1918. In the following decades, the Russian Revolution upset the existing political order in Europe. This order had been already badly destabilised by the ravages of World War I, soon to be followed by the abolition of three more empires (Austro-Hungarian, German, and Ottoman). The impact of the Russian Revolution on the world was significant: it influenced it in a myriad of ways and with varying intensities on six continents. It generated a deep ideological and political conflict between the new communist state and other powers whose troops invaded the territory of the defunct Russian Empire in 1918. This conflict contributed to the outbreak of World War II, during which the Soviet Union fought in a temporary alliance with the liberal "Western" powers. After 1945 the same conflict re-emerged and constituted the declared key ingredient of the "Cold War" between the liberal "West" and the communist "East". However, the subsequent

1 Richard Pipes, The Russian Revolution (New York: Alfred Knopf, 1991), 489-99.

2 Vladimir J. Lenin, Država in revolucija in drugi spisi iz l. 1917 (Ljubljana: Studia Humanitatis, 2017), 38-49, 169-76. 
resumption of the conflicting relations between the "West" and post-Soviet Russia reveals that the main component of the ideological clash between liberalism and communism actually disguised its basic component: the struggle for power, influence, and domination, essentially between the Americans and the Russians.

The Russian Revolution has tangibly influenced the course of human history in the $20^{\text {th }}$ century as well as contributed to considerable changes on the political map of two continents - Europe and Asia. The most immediate impact of the Russian Revolution was expressed (1) by the geographic expansion of Soviet or Soviet-like political, economic and social systems imposed on other countries by the Russian Bolsheviks and later by the Soviet communists. The Russian Revolution also exerted (2) a notable political, ideological, as well as cultural influence on other countries on all continents. The Russian example served as (3) an inspiration in a number of countries where the local communists managed to take over the power in the state predominantly or exclusively through their own efforts. Having declared the people's right to self-determination, the Russian Revolution strongly challenged imperialism and national oppression in a number of multinational states, including those in Europe. Its proclamations echoed in the colonies as well as in the semi-colonial dependencies of the European powers on other continents, notably in India, China, and Vietnam. Lenin's proclaimed slogan of people's self-determination preceded Woodrow Wilson's Fourteen Points by several months and was more far-reaching and universal - applicable to the colonies and semi-colonies of the "Western" powers as well.

Unlike in Petrograd, the takeovers in Moscow and in other parts of the already disintegrated Empire took much longer and were more difficult and bloody. The armed continuation of the October Revolution was concluded in 1921 with the termination of the Russian Civil War. Having defeated their armed opponents in Russia (Yudenich, Denikin, Kolchak, Wrangel et. al.), the Bolsheviks succeeded in imposing - by the Red Army - the Soviet system on most of the former territory of the Russian Empire and in reintegrating Ukraine, Transcaucasia, Central Asia, and the Far East into a huge multinational state. The Russian Bolsheviks were more successful in this effort than the elites of the two other multinational empires the Austro-Hungarian and the Ottoman. However, they did fail in several other territories formerly ruled by the Russians, which allowed for the restoration of Poland's independence and for the creation of new independent states in Finland, Estonia, Latvia, and Lithuania. In 1919, the attempts at revolutions, inspired by the Russian October, were crushed in Germany, Hungary, and Slovakia. Several other communist revolts elsewhere in Europe (including in Yugoslavia in 1929) also failed. In the 1920s, the Soviet system expanded, by means of military force, in Asia - to two peripheral Chinese territories bordering on the Soviet Union: Tuwa and Mongolia. Tuwa was later annexed by the Soviet Union, while the People's Republic of Mongolia became formally an independent, later internationally recognised state and a member of Organisation of the United Nations. 
In the 1920s and 1930s, the ideas and slogans of the Russian Revolution generated a considerable political impact in the war-ravaged Europe. Its messages of peace, social justice, equality, and of peoples' self-determination had attracted and motivated many leftists on all continents. On the other hand, the Bolshevik victory indirectly contributed to internal divisions in the socialist and social-democratic parties, which used to belong to the dissolved Second Socialist International. In many European countries, communist parties sprung from their left wings.

In the 1920s - 1930s, the strongest communist parties in Europe outside the Soviet Union developed in Germany, France and Spain; and after World War II also in Italy. However, none of them were able to stage a communist revolution on their own or to take over the power through elections. On the other side of the political spectrum, the October Revolution provoked strong anti-communist reactions in the rest of Europe and in Northern America. It affected a number of mainstream political parties, the extreme right, and the established churches, particularly the Roman Catholic Church. Russian Bolshevism and the Soviets of workers influenced the development of the German system of Mitbestimmung and the ideology of the German National Socialist Workers' Party (NSDAP). Moreover, the fear of communism contributed significantly to the emergence of several varieties of European fascism, including Catholic clero-fascism.

For about a quarter of a century, the Third (Communist) International (Comintern) was the main instrument for spreading the universal message of the Russian Revolution and communist ideology worldwide. This was intended to be the central organisation of the global communist movement, a unified international party with national communist parties as "sections", led from the centre in Moscow. Established in March 1919 at its first congress in Moscow, the Comintern continued to operate for more than two decades. It was officially dissolved in 1943. Its central bodies would confirm the mandate, appoint the leadership, or dissolve the communist parties outside the Soviet Union; provide them with general political guidelines and financial subsidies; decide on their strategy; offer to the communists who were persecuted elsewhere with political refuge and hospitality in the Soviet Union, new Soviet papers or forged foreign identity and documents; as well as provide medical care, general and political education, and ideological training. The Comintern maintained two universities, both located in Moscow - the "Communist University of the National Minorities in the West" (KUNMZ), and the "Communist University of the Toilers in the East" (KUTV). The Comintern also had a specialised publishing house that printed books and brochures in numerous languages and a theoretical journal with a free worldwide distribution. The Comintern combined its promotion of communist ideology, mostly through printed media, with the preparations for potential future communist takeovers in the "bourgeois" world.

Some foreign communists, including the prospective future leaders in their countries, were also provided with military, security, and intelligence training by the Red Army and by the Soviet security services. Prominent future communist leaders, 
presidents, prime ministers, ministers, and other high-ranking officials in Poland, East Germany, Czechoslovakia, Hungary, Romania, Bulgaria, and Yugoslavia were among these students. The list included also the future Yugoslav communist leader Josip Broz Tito. The Comintern also used emissaries, advisers and controllers, who oversaw groups of countries and their communist parties. One of the best known among them was Mikhail Borodin, who operated as a Comintern representative in China, Scandinavia, the United States, Mexico, Spain, and Turkey. He and a number of other Russian lecturers were vital for the establishment in 1924 as well as for the subsequent functioning of the Whampoa Military Academy in Guangzhou, Guangdong Province, China. Since the 1920s, the Comintern's educational, ideological, organisational and security training was provided in the Soviet Union to future leading communists from China, Vietnam, and Korea. The future leader of the Korean communists, first Prime Minister and later President of the People's Democratic Republic of Korea Kim Ilsung was educated and trained in Soviet military schools, and by 1945 rose to the rank of a major in the Soviet Army.

On the other hand, during Stalin's insane orgy of purges in the late 1930s, numerous communist refugees, including the leaders of Polish, Yugoslav, and Korean communist parties perished in the Soviet Union. Between 1937 and 1938, nineteen prominent Yugoslav communist emigrants were arrested in Moscow and executed on fabricated charges. Among them were five former Secretaries General (including Milan Gorkić) and nine current or former members of the Central Committee of the Communist Party of Yugoslavia. The estimated total number of Yugoslav communists executed in the Soviet Union in 1938 is around sixty.

The Soviet Bolsheviks (officially renamed to communists) considered and justified these activities (and the expense for USSR) as crucial for the active defence of the first socialist state "of workers and peasants" in history. In most countries outside the Soviet Union, the Comintern's activities were officially considered as politically subversive, even seditious and criminal (including in the Kingdom of Yugoslavia). The Comintern's internal security service and the OMS (International Liaison Department) played an important role in the Comintern's clandestine activities. Both partly overlapped with and were controlled by the Soviet civilian and military security and intelligence services (OGPU, GRU). A considerable part of the Comintern's political activities was channelled through an extensive network of international "transmission" associations, such as the Communist Youth International, Red Trade Union International, Peasant International, Red Mutual Assistance, the corresponding women's organisation, etc. The Comintern's activities, including its clandestine operations, were supported by the Soviet diplomatic and consular missions abroad.

The World War II and its aftermath provided new opportunities for the geographic spreading of Soviet-like communist regimes. Between 1939 and 1940, three Baltic republics and parts of Poland and Romania were occupied and annexed by the USSR in accordance with the secret clauses of the Molotov-Ribbentrop Pact. The defeat of the 
Axis in 1945 was followed by the imposition of Soviet-like systems in seven "people's democracies" in Eastern Europe and North Korea. Moreover, in 1945 the victorious communists in Yugoslavia and Albania implemented their own versions of the Soviet system. In 1946 the Soviets attempted to create a similar regime in Northern Iran as well, but had to abandon the attempt under the British and American pressure. In 1979 the Soviet Army invaded Afghanistan in order to prop up a crypto-communist regime in that Asian country, but later had to give up this attempt after considerable expenses and losses.

The spreading of Soviet-like systems into the Eastern Europe and Asia corresponded to two key strategic objectives of the Soviet leadership. These included: (1) the declared goal of advancing "socialism" worldwide; and (2) making the Soviet Union a global political and military superpower. Joseph Stalin made use of the appeal of the Russian Revolution in order to advance and satisfy the Soviet Union's (essentially Russian) great power ambitions. Achieving these two objectives was costly and not always compatible. On a number of occasions they collided, and then the latter would always prevail. The non-aggression pact with Hitler in 1939 was among such examples.

Following its official dissolution in 1943, a number of the Comintern's functions continued in the form of mostly bilateral relations between the Communist Party of the Soviet Union and other communist parties. In 1947 the Communist Information Bureau (Cominform) was established at a conference in Poland, mostly tasked with guiding and disciplining the East European communist parties. It was also joined by the two largest West European communist parties (the Italian and the French). Originally the seat of the Bureau and the editorial office of its newspaper were located in Belgrade. The editor-in-chief of the newspaper was a Soviet citizen with a diplomatic status, while a representative of the Communist Party of Yugoslavia Boris Ziherl served as his deputy. However, in June 1948 the Yugoslav Communist Party was expelled from the Cominform and its office was consequently relocated to Bucharest.

Outside the territory of the former Russian Empire, Russian Bolshevism decisively influenced the destiny of two Asian and two European states. The Republic of Mongolia and the People's Democratic Republic of Korea owe their very existence as independent states to the Soviet Union. In the past this was also true of the German Democratic Republic (GDR). The ideological impact of Bolshevism was crucial for the rebirth and forty-five years later for the violent demise of Yugoslavia, as well as for the peaceful dissolution of the GDR and Czechoslovakia.

Banned in December 1920, the Communist Party of Yugoslavia (the CPY) suffered greatly from the police and judicial repression in Yugoslavia as well as elsewhere. In addition to the underground membership in the country, its leadership and about a thousand of its adherents operated abroad, as migrants or political refugees (mostly in the Soviet Union, France, Austria, and during the civil war also in Spain). The Soviet organisational, logistic and financial support helped the severely weakened and politically marginalised party to survive. In the late 1930 s, with a new generation 
of young members and a new leadership, the Yugoslav communists abandoned their sectarianism and started cooperating with other anti-fascists. However, under normal peacetime conditions - without the tremendous upheaval and the profound social and political dislocation caused by the World War II - the Yugoslav communists would have probably never assumed power in the state by means of elections.

Financially self-sustaining without any Soviet subsidy since 1939, under the conditions of World War II and of the foreign occupation as well as at a considerable distance from Moscow, the Yugoslav communists managed to emancipate and free themselves from outside control. Their leadership did continue to report to Moscow by radio, but adopted its own political strategy and managed its affairs independently. At several junctions, the actions of the Yugoslav leadership deviated from the Soviet positions and tactics regarding the Western Allies. As a centralised and disciplined Party without internal fractions and with motivated adherents and supporters, the Yugoslav communists, in spite of the initially modest membership, proved to be the best organised armed resistance force on the territory of the defunct Yugoslav monarchy. The line of resolute resistance that was adopted by the communists resulted in large numbers of non-communists joining on patriotic grounds the Yugoslav Partisan movement. The organisational legacy of the Russian Bolsheviks, transmitted through the Comintern, as well as the appeal of an egalitarian ideology contributed to the Yugoslav communists' ending up on the winning side of the war. As of 1943, the British and the Americans recognised the Yugoslav Partisans as the most effective Allied force in the Balkans. In the autumn of 1944 the Soviet Army liberated part of Yugoslavia's territory, but unlike elsewhere in occupied Europe (except in Albania), in the final stages of World War II the Yugoslav Partisans succeeded in liberating most of their country on their own. The war's outcome allowed the communists to defeat, drive away or eliminate the internal adversaries who had collaborated with the occupiers. In resolutely and often brutally dealing with them, the Yugoslav communists employed the methods of their role models - the Russian Bolsheviks.

Imitating the Soviet system and adhering to Marxist-Leninist ideological precepts became a general rule in post-1945 Yugoslavia. A significant part of the first constitution of the new Yugoslav state, adopted in 1946, was merely a translation of the Soviet ("Stalin's") Constitution of 1936. The Yugoslav communists adopted thus the Soviet system of fake ethno-federalism, with often artificial administrative lines separating the federal units. In many respects, the Yugoslav communists strived to be and indeed were more orthodox and Stalinist in terms of their "revolutionary" approach than the other European communist parties. The Yugoslav adaptation of the Russian Bolshevik ideology replaced the pre-war ideological foundation of the Kingdom of Yugoslavia and became the first and foremost adhesive element of the newly stitched-together multinational state called the Federal People's Republic of Yugoslavia.

Initially the Yugoslav communists responded to the sharp conflict with Stalin in June 1948 and to the insulting expulsion from the Eastern European "camp of 
people's democracies" with an even more Marxist orthodoxy and Stalinism in internal political and economic matters. Only after 1951 did the political shock resulting from the conflict with Moscow led to gradual and partial liberalisation of Yugoslavia and its distancing from the Soviet system. The hallmarks of the Yugoslav "revisionist" system included workers' self-management, semi-market economy, relatively open borders, and non-alignment in international affairs. However, the Yugoslav communist leaders, like the Soviets, continued to wrongly believe that the "socialist revolution" had resolved forever the national problem in their multinational state. Because of the pressure from below, in 1963 and in 1974 the Yugoslav authorities made concessions to the centrifugal forces and allowed for the transformation of the centralised quasifederation into a malfunctioning hybrid of a federal - confederal institutional structure and authoritarian one-party rule. With the waning attraction of the egalitarian communist ideology, the "revisionist" deviations from the Soviet model proved to be insufficient to keep the Yugoslav state in one piece. Not accidentally, the modified imitation of the Soviet system in Yugoslavia went down the drain of history roughly at the same time as its original form in the Soviet Union.

The dissolution of the Warsaw Pact in 1991 marked the end of the Soviet hegemony in a significant part of Eastern-Central and South-Eastern Europe. It was accompanied by the crumbling of European communist regimes and the end of the "Cold War". These dramatic developments allowed for an important geopolitical transformation and realignment on the European continent. Four communist-ruled "real-socialist" states disappeared from the European map. Among them were three "socialist federations" (the Union of Soviet Socialist Republics, the Socialist Federal Republic of Yugoslavia, and the Czechoslovak Socialist Republic). Nowadays, twentyfour new European states exist on the territories of the three defunct federations. Of these, seven republics on the territory of the former SFR Yugoslavia have become independent also due to the delayed political and ideological impact of the Russian October Revolution.

Between the 1920s and the 1930s, the Russian October Revolution and the Comintern contributed significantly to the development of Chinese communism. The popularity of the Bolsheviks in the semi-colonial China was enhanced by their anti-imperialist pronouncements and the declared intention to renounce Russia's extraterritorial rights. In the spring of 1920, Grigorii Voytinski, a Comintern emissary, helped to establish the Communist Party of China and drafted its manifesto, which was adopted at the first party congress. In the 1920s and 1930s, the future important communist functionaries like Deng Xiaoping, Zhou Enlai and others attended the ideological and organisational training in Moscow, at the Communist University of the Toilers in the East. The adopted Bolshevik organisational format and internal rules of a centralised and disciplined party as well as the Comintern's annual subsidy greatly helped the Chinese communists to survive persecution and eventually to emerge victorious in the guerrilla warfare against the Japanese occupiers and in the civil war that lasted for two decades. The Whampoa Military Academy, Soviet advisors and 
instructors in China, and military schools in the Soviet Union contributed to the military education and training of some generals of the Chinese People's Liberation Army (PLA) who became later quite famous. In the final stage of the civil war, the strength of the PLA was enhanced by the captured weapons of the Japanese Kwantuing Army in Manchuria, crushed by the Soviet Army in August 1945.

Having gained the state power on the mainland in 1949, the Chinese communists adopted and largely followed the Soviet model of state organisation as well as economic and social development. There have been several notable exceptions. Mao Zedong disagreed with the Russian Bolshevik concept of a "workers' revolution" and opted instead for the strategy of a "peasants' revolution". Moreover the Chinese communists eschewed the Soviet model of ethno-federalism, granted only limited cultural autonomy to ethnic minorities and organised mass relocations of the Han population to the strategically-important peripheral provinces. In addition they, unlike the Soviets, allowed the continued existence and controlled legal functioning of eight "fellow" and "patriotic" parties, small by the Chinese standards. After two disastrous experiments in the 1950s, 1960s and 1970s - with Mao Zedong's "Great Leap Forward" and the "Cultural Revolution" - the Chinese communist leadership under Deng Xiaoping abandoned the Marxist economic dogmas. Moreover, unlike in the Soviet Union, the Chinese leadership introduced and, until 2018, maintained a system of regular mandatory rejuvenation of the top personnel in the state, based on the criteria of proved competence, managerial ability, and personal achievements.

V. Lenin, the spiritual leader of the October Revolution, was feared that the Soviet Russia will not survive without a global socialist revolution ${ }^{3}$. The Revolution's militry leader L. Trotsky claimed, in his work "The Permanent Revolution", that a socialist revolution could not be accomplished in a national framework ${ }^{4}$. For more than three decades, the prospect of a world revolution seemed unattainable. However, the future of world communism became brighter by the $40^{\text {th }}$ anniversary of the October Revolution, which was solemnly celebrated in November 1957 in Moscow. Conspicuously present at the event were the leaders of the territorially largest and the most populous states on the globe (the USSR and the People's Republic of China) as well as of a dozen "people's democracies". During the following two and a half decades, the pseudo-communists rose to power on Cuba, in Kampuchea, South Vietnam, Laos, Angola, Mozambique, Ethiopia, South Yemen, Afghanistan, Grenada, and Nicaragua. All these achievements seemed to foreshadow the communist future of mankind. However, soon after the $70^{\text {th }}$ anniversary Lenin's premonition turned out to be correct.

Lenin and Trotsky were wrong in their assumption that the communist system could only be defeated if crushed militarily from the outside by "bourgeois" imperialism. Instead the communist systems in the Soviet Union and in Eastern Europe broke down because of internal reasons. Ultimately, the demise of the Soviet

3 Louis Fischer, The Life of Lenin (New York: Harper \& Row, 1964), 309-13, 528, 622.

4 Lav Trocki, Permanentna revolucija (Rijeka: Otokar Keršovani, 1972), 131. 
system and the systems of Eastern European "people's democracies" has resulted from flawed economic strategies, inflexible authoritarian political systems, and the challenges posed by nationalism (which was supposed to disappear in the communist societies). The Soviet Union collapsed also due to its leadership's grossly excessive global superpower ambitions, to the ensuing economic exhaustion, the cancer of the ethno-federalist façade, and a conflict within the Russian political elite. In the last decade of the $20^{\text {th }}$ century, all communist-led or dominated "real socialist" systems in Eastern Germany, Central Eastern and South Eastern Europe, in Russia itself, in all other former republics of the Soviet Union (with the possible exception of Belarus), and in Mongolia experienced ostensibly liberal, mostly non-violent counterrevolutions. They were replaced by very different systems, ranging from multiparty parliamentarian democracies to various kinds of autocracies and personal or family dictatorships behind the imitations of liberal constitutional façades. All these regimes deny any continuity with the heritage of the Russian Revolution.

Lenin and Trotsky did not believe that Soviet-like systems would still survive elsewhere, if defeated in Russia. Once again, it turned out that they were wrong. Communist systems inspired directly or indirectly by the Russian Revolution, partly copied from the Soviet model but developed indigenously, have been created "through the barrel of the gun" and have developed in Eastern Asia. Today, one of them - a radical totalitarian and militarised replica of the Soviet system in the People's Democratic Republic of Korea - does not capture the world's attention with the wellbeing of its population, but rather with its successful development of nuclear weapons and long-range missiles. The list of geographically more distant followers also include the current systems in the Republics of Laos and Cuba. An aberrant, brutal imitation of wartime Bolshevism by the "Khmer Rouge" existed for several years in Kampuchea, but was crushed militarily by the Vietnamese communists.

The economically and politically most successful "socialist" state - the People's Republic of China and to a lesser degree the Socialist Republic of Vietnam - have developed and maintained several essential elements of the systems inspired by the Russian revolution: a ruling communist party, an official Marxist - Leninist ideology, mass rituals, red flags, five-pointed stars, and other communist symbols. Having abandoned however the Marxist economic dogmas, the Chinese and Vietnamese communists combined the Soviet-like political features of their political systems with a considerably open and controlled market economy, a large share of private domestic and foreign capitalism, and gross economic inequality. These deviations from the Soviet model released the energy of hundreds of millions of Chinese. In three decades they have transformed the still communist China into the second largest world economy and a great political and military power. Since the implementation of reforms inspired by Deng Xiaoping, the Chinese communists could be considered as followers of the Soviet "New Economic Policy" (NEP) in the 1920s, which could be observed first-hand by Deng Xiaoping, at the time a student of the Communist University in Moscow. However, this policy was soon abandoned by the frightened 
and dogmatic Soviet officialdom. In retrospect, that turnabout and the ensuing suppression of private economic activities in the Soviet Union was one of the fatal errors committed by the Russian Bolsheviks.

The Russian October Revolution was much more radical in its proclaimed goals and much more violent than the American Revolution of 1775-1783. It also lacked the latter's main secessionist element. However, when constructing the Soviet Union, the Russian Bolsheviks copied some institutional features of the American federalism. In a number of respects, the Russian Revolution could be more appropriately compared with the Great French Revolution of 1789-1792. The storming of Bastille in Paris and of the Winter Palace in Petrograd became the symbols of these revolutions, both of which occurred in the largest European states of that time and shook profoundly the existing social and political orders in Europe. The French Revolution abolished feudalism in France and contributed to its gradual abolition in the rest of Europe. The Russian Revolution, on the other hand, swept away the remnants of feudalism in Russia. Unlike the American revolution, both anticlerical revolutions soon degenerated into dictatorships. The liberating appeal of both of them was abused by the two dictators for conquests and domination in considerable parts of the European continent. The two dictators who came from minorities - Napoleon Bonaparte and Joseph Stalin - thus betrayed the declared goals of the two revolutions.

Both revolutions were eventually defeated in the countries of their origin (and in their satellite states), but left deep impact on their societies. For more than a century, the ideas of the French Revolution would inspire reformers and revolutionaries in Europe and the Americas, and would be subsequently built into the political and social orders of liberal democratic states on five continents. The French Revolution also contributed to the decolonisation of North and South America, while the French Jacobins influenced many radical leftists around the globe, including the Russian Bolsheviks.

The Russian October Revolution failed in its declared primary strategic objective: to destroy and abolish capitalism all around the world. Contrary to their original promise of "the complete abolition of the state", the Russian communists developed a bureaucratic monstrosity. On the other hand, the fear of communism, helped to reform the crude capitalist systems in the West in the direction of more democratic and human social states. The first communist state - the Soviet Union - contributed decisively to the military defeat of the German-Austrian Third Reich and to the victory of the Allies in the World War II. The Russian Revolution also contributed to the decolonisation in Asia and Africa, and indirectly to the rebirth of China as a global superpower.

On the other hand, certain features and symbols of the Russian Revolution have become discredited in many countries with authoritarian communist regimes. Geographically, this discreditation was rather random. During the last three decades in addition to 30 European, Transcaucasian and Central Asian countries, communist parties have lost state power in four Asian countries (Afghanistan, Kampuchea, 
Southern Yemen, Nepal); six African countries (Ethiopia, Somalia, Benin, Angola, Mozambique, Congo, Brazzaville); and in two states in the Americas (Grenada, Nicaragua). Nowadays communist parties rule only in four East Asian and one Latin American state. In addition, the communist parties in Asia (India, Bangladesh, Nepal, Syria and Palestine); Africa (South Africa) and Latin America (Chile, Ecuador, Uruguay, Guyana and Venezuela) have participated in the ruling leftist coalitions. The Communist Party of Japan currently holds 14 seats in the upper house of the Japanese National Assembly. Most European communist parties have either been dissolved or reformed, reorganised and renamed, usually into socialist or social-democratic parties. Three small communist parties participate today in the ruling coalitions in Greece, Serbia and San Marino while notable non-ruling communist parties function in the Russian Federation, Czech Republic, Portugal, Spain, Italy, France and Cyprus. 15 deputies of the European Parliament (out of 751) have been elected from the lists of seven European communist parties.

The discreditation of the October Revolution in its country of origin explains why the post-Soviet Russian regime has stopped celebrating the $7^{\text {th }}$ of November and removed it from the list of official holidays. The Americans and the French, on the other hand, continue to joyfully celebrate every year the $4^{\text {th }}$ and $14^{\text {th }}$ of July as their main state events. The Russian October Revolution has thus primarily become intellectual food for historians and other social scientists, as well as a topic for writers, film and television producers, and for other media.

\section{Sources and Literature}

\section{Literature}

- Fischer, Louis. The Life of Lenin. New York: Harper \& Row, 1964.

- Lenin, Vladimir J. Država in revolucija in drugi spisi iz l. 1917. Ljubljana: Studia Humanitatis, 2017.

- Pipes, Richard. The Russian Revolution. New York: Alfred Knopf, 1991.

- Trocki, Lav. Permanentna revolucija, Rijeka: Otokar Keršovani, 1972.

\section{Online Sources}

- List of communist parties - Wikipedia. Accessible at: https://en.wikipedia.org/wiki/List_of_ communist_parties, 19 March 2018.

5 List of communist parties - Wikipedia. 


\section{Anton Bebler}

\section{O GLOBALNEM UČINKU RUSKE OKTOBRSKE REVOLUCIJE IZ LETA 1917}

\section{POVZETEK}

Ruska revolucija, se je dejansko začela februarja -marcal. $1917 \mathrm{z}$ ukinitvijo ene od najstarejših monarhij v Evropi in $\mathrm{z}$ uvedbo deljene vladavine začasnega odbora Dume ( $\gg$ Začasna vlada $\ll$ ) in $\gg$ Sovjetov odposlancev delavcev in vojakov.« Do sredine oktobra 1917 je Vojaškorevolucionarni odbor Petrograjskega sovjeta že nadzoroval rusko prestolnico. Aretacija večine ministrov nemočne Začasne vlade v Zimski palači v Petrogradu ponoči 26. oktobra in strel s slepim nabojem s križarke $\gg$ Avrora $\ll$ sta bila le epizoda, ki so ju propagandno napihnili v simbola slavne Oktobrske revolucije v največji evropski državi. Prevzem oblasti v Moskvi in drugod po državi pa je bil veliko težji, bolj nasilen in krvav. Ruska revolucija se je zaključila šele 1.1921 z zmagami ruskih »boljševikov《 in Rdeče armade v krvavi državljanski in drugih vojnah. Te vojne, drugo nasilje, lakota in epidemije na ozemlju propadlega cesarstva so terjali $\mathrm{v}$ štirih letih nekaj milijonov smrtnih žrtev.

Ruska revolucija je pretresla tedanjo politično ureditev v Evropi, ki jo je že pred tem hudo razmajala prva svetovna vojna, kar se je izrazilo tudi v propadu še treh velikih cesarstev -avstroogrskega, nemškega in otomanskega. Za razliko od drugih prevratov je Ruska revolucija pozivala $\mathrm{k}$ popolni odpravi svetovnega kapitalizma in imperializma ter $\mathrm{k}$ uvedbi brezrazrednih družb $\mathrm{v}$ svetovni federaciji sovjetskih republik kot koraka k odpravi države. Ruska revolucija je odmevala v svetu na več načinov. Njen najbolj neposredni mednarodni odtis se je v naslednjih treh desetletjih izrazil: v (1) nastanku političnih, ekonomskih in družbenih sistemov, podobnih sovjetskemu, ki so jih na druge dežele razširili predvsem ruski oz. sovjetski komunisti; (2) v vplivu na politično sceno v več drugih državah, ki se je izražal, med drugim, $\mathrm{v}$ nastanku komunističnih partij in v protikomunistični reakciji; (3) v vzpostavitvi nekaj avtohtonih komunističnih režimov, ki so delno posnemali sovjetski sistem.

$\mathrm{V}$ sedmih desetletjih od zmage v svoji domovini Ruska revolucija ni odpravila ne svetovnega kapitalizma in ne same države, povzročila pa je velike geopolitične spremembe, predvsem v Evropi in Aziji. Strah pred komunizmom je posredno pomagal reformirati grobi kapitalizem na Zahodu v smeri bolj humane in demokratične socialne države. Število »socialističnih« držav, seštevek njihovih ozemelj in prebivalstva so dosegli svoje vrhunce kmalu po 40. obletnici Ruske revolucije, ki so jo v novembru 1957 slovesno obeležili v Moskvi. Ruska revolucija je poleg tega prispevala $\mathrm{k}$ dekolonizaciji v Aziji in Afriki.

Po sedmih desetletjih od zmage pa so bili v zadnjem desetletju 20. stoletja, večinoma po mirni poti, odpravljeni komunistični sistemi v sami Rusiji, vseh drugih 
nekdanjih republikah Sovjetske zveze (z morebitno izjemo Belorusije), vseh drugih vzhodnoevropskih državah (vključno z Vzhodno Nemčijo) ter Mongoliji. V primerjavi z vrhuncem okrog 1.1960 se je število »socialističnih « držav v svetu tako skrčilo za dve tretjini na sedanjih pet, od teh na štiri v Aziji in eno v Latinski Ameriki.

Kot posnemovalci ruskih komunistov so se izkazali predvsem komunisti v Vzhodni Aziji. Svojevrstna, močno militarizirana imitacija sovjetskega sistema v Severni Koreji priteguje danes pozornost svetovne javnosti predvsem s svojim razkazovanjem jedrske in raketne oborožitve. Veliko bolj politično in gospodarsko uspešni kitajski komunisti so povezali politične poteze, povzete po sovjetskem sistemu (vladavino komunistične partije, uradno marksistično ideologijo, množične rituale, rdeče zastave, peterokrake zvezde in druge simbole), s tržno ekonomijo, veliko vlogo zasebnega domačega in tujega kapitala ter visoko ekonomsko neenakostjo.

$\mathrm{Za}$ ruske in druge vzhodnoevropske režime pa je bilo usodno, da se niso odrekli protitržnim marksističnim dogmam in vztrajanju na avtoritarnem oblastem monopolu. Razpadu Sovjetske zveze, ČSSR in SFRJ sta botrovala tudi od zgoraj vsiljeni model fasadnega etnofederalizma in zgrešeno verovanje, da socializem odpravlja nacionalna protislovja. Še posebej v Evropi so dediščino in simbole Ruske revolucije politično diskreditirali avtoritarni vzhodnoevropski komunistični režimi in še posebej totalitarni režim v Sovjetski zvezi, katere gospodarstvo ni zdržalo tekme $\mathrm{z}$ razvitim Zahodom. To je bil temeljni razlog, zakaj so v Ruski federaciji odpravili praznovanje 7. novembra. Ruska revolucija je tako postala predvsem tema za zgodovinarje, druge družboslovce in umetnike. 